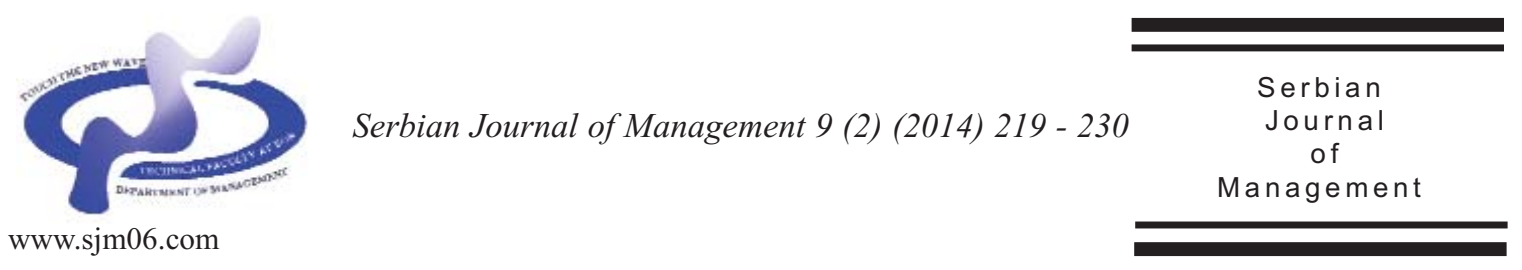

\title{
THE ROLE OF QUALITY METHODS IN IMPROVING EDUCATION PROCESS: CASE STUDY
}

\author{
Dragan Pavlović*, Milena Todorović, Srđan Mladenović and Peđa Milosavljević \\ Faculty of Mechanical Engineering, University of Niš, \\ 14 Aleksandra Medvedeva,18000 Niš, Serbia
}

(Received 20 February 2014; accepted 15 Jul 2014)

\begin{abstract}
This paper presents a methodology for applying the Lean Six Sigma method on the educational process. After defining defects that have negative influence on the final quality evaluation of higher education and how these defects can be remedied, the Pareto analysis is done, and that is used for establishing a vital minority of the exams that are critical for examination of faculty. The next step is the Statistical Process Control (SPC) analysis that is performed on the exams that are classified as vital minority in Pareto analysis. Ishikawa diagram shows a relation between considered consequence (small number of passed exams) and all factors that influence this consequence. Based on the results of implementation of the Lean Six Sigma method in the educational process and implementation of all suggested improvements, the comparative overview of Pareto analysis is given for 2009/2010 and 2012/2013 academic year at the Faculty of Mechanical Engineering, University of Niš.
\end{abstract}

Keywords: Lean, Six Sigma, Education, Pareto, SPC, Ishikawa Diagram.

\section{INTRODUCTION}

Higher educational institutions, like faculties face some challenges as a consequence of greater competition for resources, stronger opposition from new providers of higher education, and significantly reduced public funding. Also, there will be even greater pressure to be competitive with new forms of learning, new technologies for teaching, and new requirements for students' competences.

\footnotetext{
* Corresponding author: draganpavlovic10369@gmail.com
}

DOI:10.5937/sjm9-5538 
Against this background, the need for educational organizations, including faculties, to carry out the market research and keep a close check on the service quality is self-evident. Quality must not represent just one of the subjects in plans and programmes of certain faculties, but also a way for reaching a competitive advantage. This is the reason why introducing quality management is important for the future university development (Tribus, 2005).

One of the possible ways to achieve the best quality of services at the lowest costs is the application of the Lean Six Sigma method. Combining Lean and Six Sigma increases the efficiency and effectiveness of processes. Lean enables simplifying and speeding up the process by reducing or eliminating waste. On the other hand, Six Sigma reduces the variation in the process and reduces or eliminates defects from the process (Bhuiyan \& Baghel, 2005).

The aim of this paper is to show the possibility of implementing the Lean Six Sigma method in an educational process and to present the results after applying the Lean Six Sigma method in the first academic year in Faculty of Mechanical Engineering University of Niš in Serbia.

For the purpose of determination of root causes of the small number of passed exams, the survey of the 80 students of the first and second academic year has been done.

\section{LEAN SIX SIGMA METHODOLOGY IN HIGHER EDUCATION}

Applying Lean Six Sigma method, which is used mainly in industrial processes, can be very challenging. In order to improve service quality in an educational process it is necessary to define the quality first. Some authors defined the quality of education as "the ability of student's knowledge to satisfy stated requirements" (Karapetrovic \& Willborn, 1997). As many authors agreed that the major difficulty in improving quality in education process lies in the definition of a "customer". Students at Wright State University recognized themselves as the customers in a higher educational process (Helms \& Key, 1994) in the survey that was done. Not only those faculties did not take always into consideration that students could be presented as customers, but also faculties often saw students as raw material (Ewell, 1993). Students can also be classified into groups as the raw material, customers, or even as employees. Students as raw material are those that are going through the process and that are becoming the final product. Students as customers are purchasing the service of education. In addition, students as employees are those that should be involved in their studies and they should be motivated to perform and those students are evaluated at the end. It can also be said that the quality of student's performance should be important for a university in the same way in which the quality of an employee's performance is important for a company.

The reasons why it is difficult to apply industry techniques on an educational process point out the general problem. The industry techniques together with quality tools mainly begin with studying the market, or the customer's real needs. Then they focus quality of process to meet these needs. But in the education process, the motives of professors are independent of the market (Olivia \& Aspinwall, 1997). The major problem occurs in the part of education itself and then in the auxiliary or administrative areas of the educational process. Some authors stressed that "the primary activity of 
educational institutions is teaching and learning which is not a business activity itself" (Quinn et al., 2009). This process cannot be divided into teaching on one side and learning on the other.

Six Sigma emphasizes three factors, essential for an organization's success, and they are: customers, processes and employees (Banuelas et al., 2005). Customers have to be the center of the universe for an organization, because they define quality. They except a certain level of product's or service's performances, competitive pricing, just-in-time delivery, maintenance. Considering previously mentioned, processes should be observed from customers' perspective. Due to that, every enterprise should discover what customers want, and what do they really get. This kind of information will enable enterprise to increase value by improving its processes. Considering that people make results, it is necessary to motivate employees to direct their knowledge, skills and abilities towards the satisfaction of customers' needs. Therefore, the quality must be an assignment and a responsibility of each and every employee in an organization (Goh, 2010; Raisinghani et al., 2005).

Implementation of Six Sigma is grouped into five phases which make the results of their implementation superior (Hwang, 2006). The aim of this methodology is to improve the quality of process outputs by identifying and eliminating causes of defects (faults) and minimizing the variability in production and business processes (Linderman et al., 2003; Stoiljkovic et al., 2010). Application of DMAIC, which is part of Six Sigma methodology, in higher education process has been proved to be an example of good practice in problem solving in Malaysia Higher Education Institutions
(Paramasivam \& Muthusamy, 2012), as well as Continuous Quality Improvement (CQI) (Basri, 2009).

The Lean methodology is a set of methods and techniques focused on the continuous elimination of waste so that each process, task or activity adds value to the product (Womack et al., 1990; Holweg, 2007). The value is defined as an action or a process that a user would be willing to pay for. In fact, the Lean is focused on creating a value with less work (Hampson, 1999).

The highest goal of the Lean methodology is to eliminate waste. Waste is all that adds costs or consumes time without adding any value. Each activity consumes certain resources that can always be converted into currency. Toyota has identified three general forms of waste (Shah \& Ward, 2007) and they are: Muda (basic waste), Muri (overburden) and Mura (unevenness).

Waste, which can be categorized into seven basic types of waste (Womack \& Jones, 2003; Hines \& Rich, 1997) can be identified in all processes. Identified waste in the education process at the Faculty of Mechanical Engineering is shown in Table 1.

Lean production is inspired by the Kaizen, the Japanese strategy for continuous improvement (Glover et al., 2013). The word Kaizen consists of two Japanese words: kai literally means to isolate and zen - means to fix (Peitz \& Shin, 2013). As the words themselves explain, the problem should be isolated, analyzed, solved, and the solution must be implemented. Kaizen is based on Deming's philosophy and his quality circle Plan-Do-Check-Act (PDCA). This actually leads to the conclusion that these two concepts, Six Sigma and Lean, have similar or even the same roots (Shan et al., 2008; Hu et al., 2008). 
Table 1. Seven basic types of waste in the education process

\begin{tabular}{|c|c|c|}
\hline Waste & Definitions & Elimination of waste \\
\hline Defects & $\begin{array}{l}\text { Wrong teaching plan and classroom } \\
\text { schedule, mistakes upon registering for } \\
\text { exams, failed exams, withdrawing from } \\
\text { exams, incomplete or incorrect } \\
\text { information. }\end{array}$ & $\begin{array}{l}\text { Create a check list to define "what is good" } \\
\text { in the curriculum, announce student } \\
\text { requirements, following and application of } \\
\text { modern curriculum in the world, classroom } \\
\text { schedules and timetable must be displayed } \\
\text { and accessible to students and professors in } \\
\text { a visible place. }\end{array}$ \\
\hline $\begin{array}{l}\text { Buffer } \\
\text { stocks }\end{array}$ & $\begin{array}{l}\text { Students who are left back, great variation } \\
\text { in the number of passed exams in } \\
\text { different exam periods, taking the same } \\
\text { courses again for not receiving the } \\
\text { signature at the end of the previous term, } \\
\text { students who failed or withdrew from } \\
\text { taking the exam, unnecessary and } \\
\text { redundant parts of curriculum. }\end{array}$ & $\begin{array}{l}\text { Regular student attendance at lectures and } \\
\text { practise classes, introducing obligations and } \\
\text { manner in which exams are taken to } \\
\text { students at the beginning of each semester, } \\
\text { taking exams during the semester through } \\
\text { mid-term tests, project tasks, and term } \\
\text { papers. }\end{array}$ \\
\hline Motion & $\begin{array}{l}\text { Students moving from classroom to } \\
\text { classroom, not getting the information on: } \\
\text { taking exams and mid-term tests, exam } \\
\text { periods and registration, mistakes upon } \\
\text { registration, at the right place at the right } \\
\text { time. }\end{array}$ & $\begin{array}{l}\text { Conducting teaching in a single classroom, } \\
\text { designing web portals and displaying } \\
\text { information regarding exams and mid-term } \\
\text { tests in one spot and on one notice board. }\end{array}$ \\
\hline Waiting & $\begin{array}{l}\text { Information (in exams, mid-term tests, } \\
\text { exam periods), waiting to enrol in the next } \\
\text { year, students and professors being late } \\
\text { for lectures and practise classes, waiting } \\
\text { for and replacing equipment necessary for } \\
\text { teaching. }\end{array}$ & $\begin{array}{l}\text { Faster information update, implementation } \\
\text { of the Bologna Process, regular student and } \\
\text { professor attendance at lectures and } \\
\text { monthly checks of student attendance, } \\
\text { student surveys in the work of professors } \\
\text { and assistants. }\end{array}$ \\
\hline $\begin{array}{l}\text { Transport } \\
\text { ation }\end{array}$ & $\begin{array}{l}\text { Students passing from year to year, } \\
\text { information transfer from the student } \\
\text { service to the notice board regarding } \\
\text { exams and mid-term tests. }\end{array}$ & $\begin{array}{l}\text { Designing web portals and displaying all } \\
\text { information in one spot and on one notice } \\
\text { board, complete implementation of the } \\
\text { Bologna Process. }\end{array}$ \\
\hline $\begin{array}{c}\text { Over } \\
\text { processing }\end{array}$ & $\begin{array}{l}\text { Re-taking exams, re-enrolment, re-taking } \\
\text { classes. }\end{array}$ & Implementation of the Bologna Process \\
\hline $\begin{array}{c}\text { Over } \\
\text { productio } \\
\mathbf{n}\end{array}$ & $\begin{array}{l}\text { Excessive number of students who did not } \\
\text { find a job within six months of } \\
\text { graduation. }\end{array}$ & $\begin{array}{l}\text { Cooperation of the Faculty with } \\
\text { organizations and companies, giving } \\
\text { presentations - career days, organizing } \\
\text { employment fairs. }\end{array}$ \\
\hline
\end{tabular}

3. DETERMINATION OF VITAL MINORITY

In order to focus all the available resources on eliminating the causes of problems in the process, Pareto analysis can be used, which is one of the seven basic quality tools. The Pareto method is named after Wilfred Pareto - it is the principle of $80 \%-20 \%$, which states that there is a vital minority and trivial majority, i.e. that $80 \%$ of appearances is caused by $20 \%$ of the reasons (Grosfeld-Nir et al., 2007).

The Pareto analysis is based on the results 
of the exams that are not passed in the 2009/2010 academic year of the first year of academic study, obtained from the student service at the Faculty of Mechanical Engineering, University of Niš. Pareto analysis of the number of the exams that are not passed in 2009/2010 (Figure 1) shows that course Mechanics 1 - Statics make a vital minority, where the further analysis should be focused. The mentioned course is critical for the successful studying not only for the first year of academic study, but also for the entire education. One of the reasons is that the students of the first year have different background knowledge and different abilities to fit into the new environment.

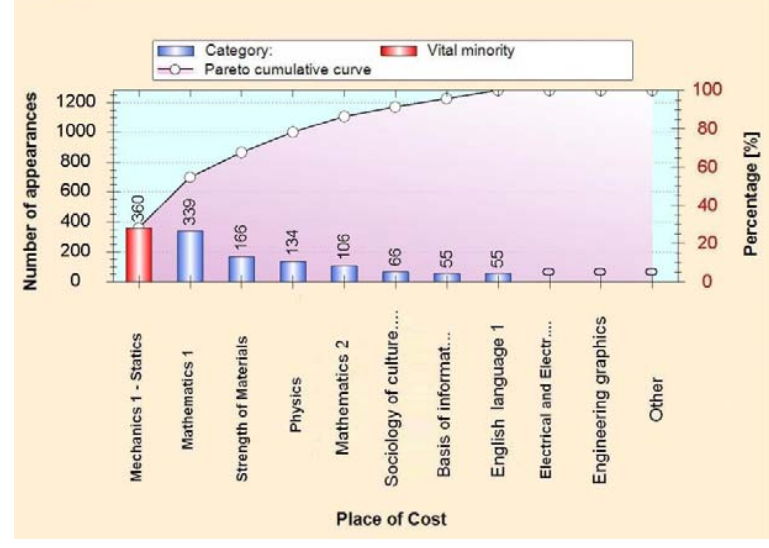

Figure 1. Pareto analysis of the exams that are not passed in the first year of academic study

The above mentioned problem should be the focus of the faculty itself, the management and the professors, in order to increase the number of passed exams in this course and the level of quality of studies. This course represents the basics of techniques. Also, the further upgrading with other courses would be inefficient. In the latest chapter measures for improvement are given in order to eliminate this problem.

\section{VARIATIONS IN THE PROCESS}

Statistical process control (SPC) is an analytical tool for making decisions that allows you to see when the process is functioning properly and when not. SPC includes using statistical signals to identify the causes of variation, performance improving and maintaining productivity control at the high quality level.

After the Pareto analysis and after obtaining vital minority of courses that are critical for passing exams, SPC is applied. First of all, it is necessary to define certain parameters in the analysis, such as control points, target value, the upper and lower specification limits. Control points represent the measured values during a certain time interval for the observed sample, while the upper and lower specification limits are the minimum values of tolerance fields outside of which the process should not vary.

Control points are the exam periods and there are seven of them: January, April, May, June, September, October I, October II and October III. Mean value, the upper

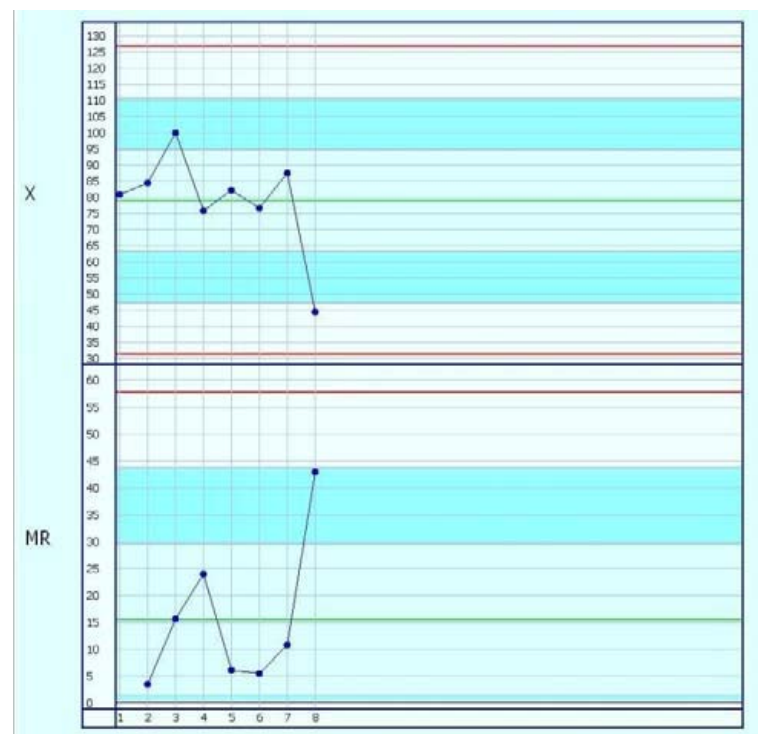

Figure 2. Control chart for the course Mechanics 1 - Statics 
specification limits and lower specification limits depend on the number of exams that are not passed expressed in $\%$.

According to the control chart of the observed course, it can be noted that the process varies a lot and one part of chart is outside the specification limits. Based on the Figure 2, it can be concluded that the number of the exams that are not passed is very high in all exam periods except from the last exam period - October III. The aim of the improvement of the educational process is to reduce this variation and to minimize the number of exams that are not passed, i.e. it is necessary that both the target value and tolerance field between the specification limits are as low as possible.

\section{DETERMINATION OF RELATION BETWEEN CONSEQUENCE AND CAUSES}

Ishikawa diagram is a tool that helps in identification, sorting, and displaying possible causes of a specific problem or quality characteristics. The diagram graphically shows the relation between specific consequence and all factors that influence the consequence (Ishikawa, 1982; Enarsson, 1998).

The diagram is constructed by starting from the consequence which is inserted in the right side of the diagram. Further step is drawing of the "fishbone" diagram and attaching categories to it. The diagram is developed by considering all categories and asking WHY a certain category affects the result. For every cause, the same process of construction is repeated, and the question WHY is asked for every level. It can be concluded that the method for constructing Ishikawa diagram consists of considering all possible causes and their organization into categories and subcategories.

Considered causes of the problem in production are usually divided into seven categories and these categories are: Man, Machines, Material, Method, Measure, Management and Milieu (environment).

In this case, the considered consequence is Small number of passed exams (Figures 3 to 5).

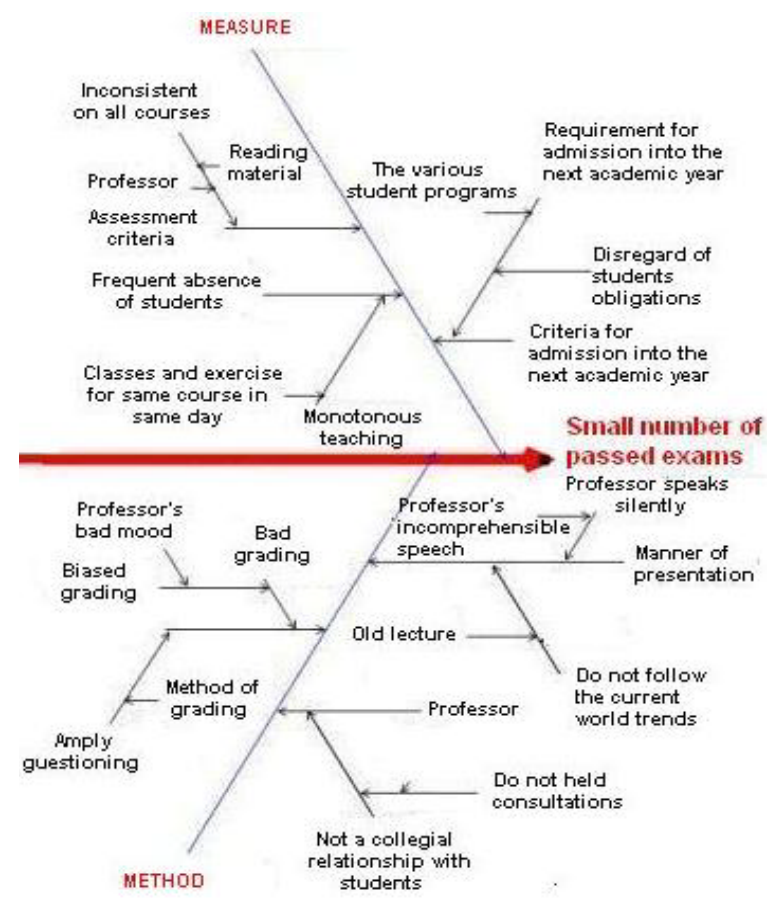

Figure 3. Categories Measure and Method

The presented Ishikawa diagram is done also on survey, which is taken by the most students on the first and second academic year. Student voice can be taken as very important for further investigation, because it has the significant role for forming the future curriculum of the faculty. It is needed to reconsider not only individual point of view but also socio-cultural view of the students and their environment (Scott \& Leach, 2003). 


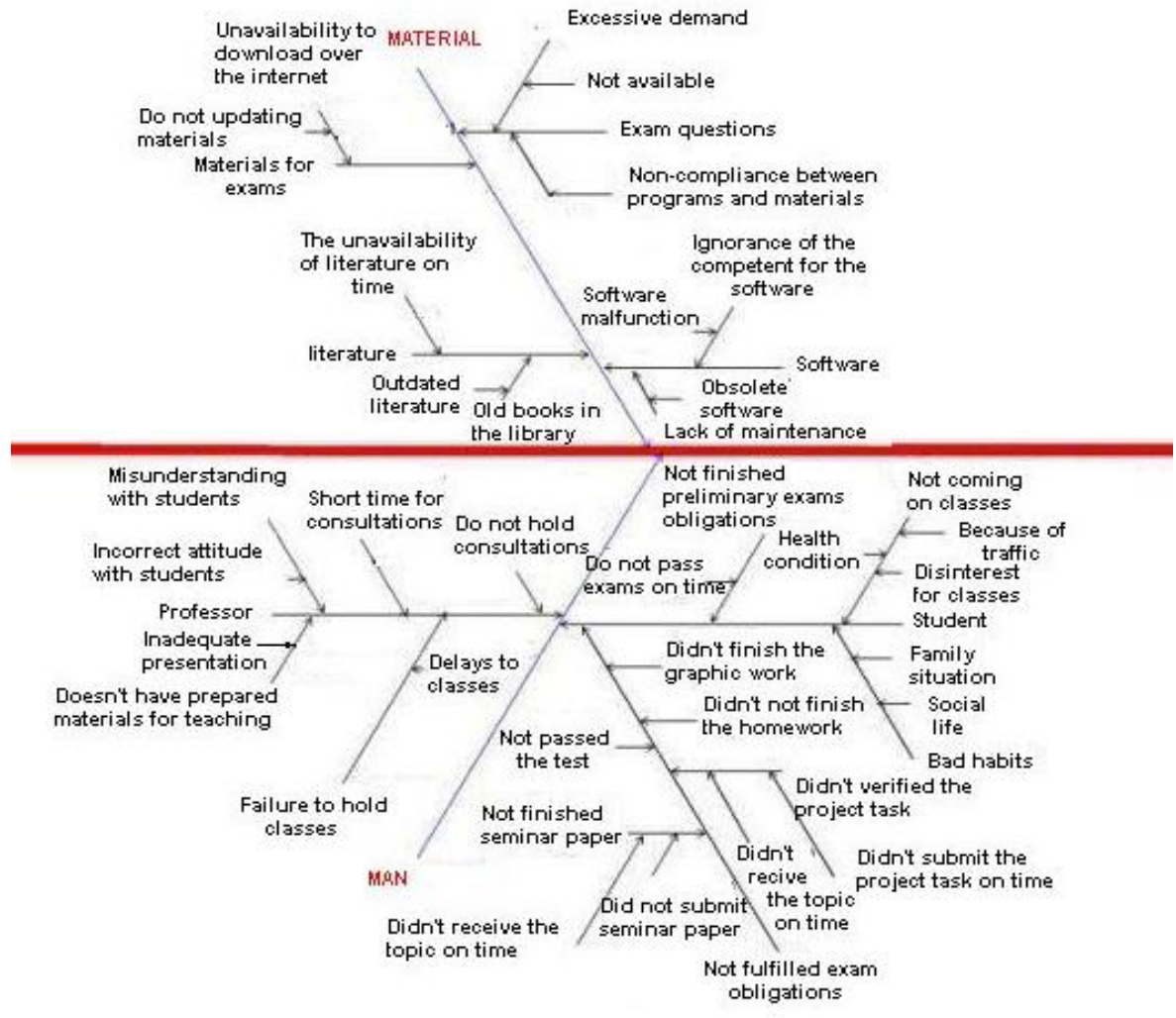

Figure 4. Categories Material and Man

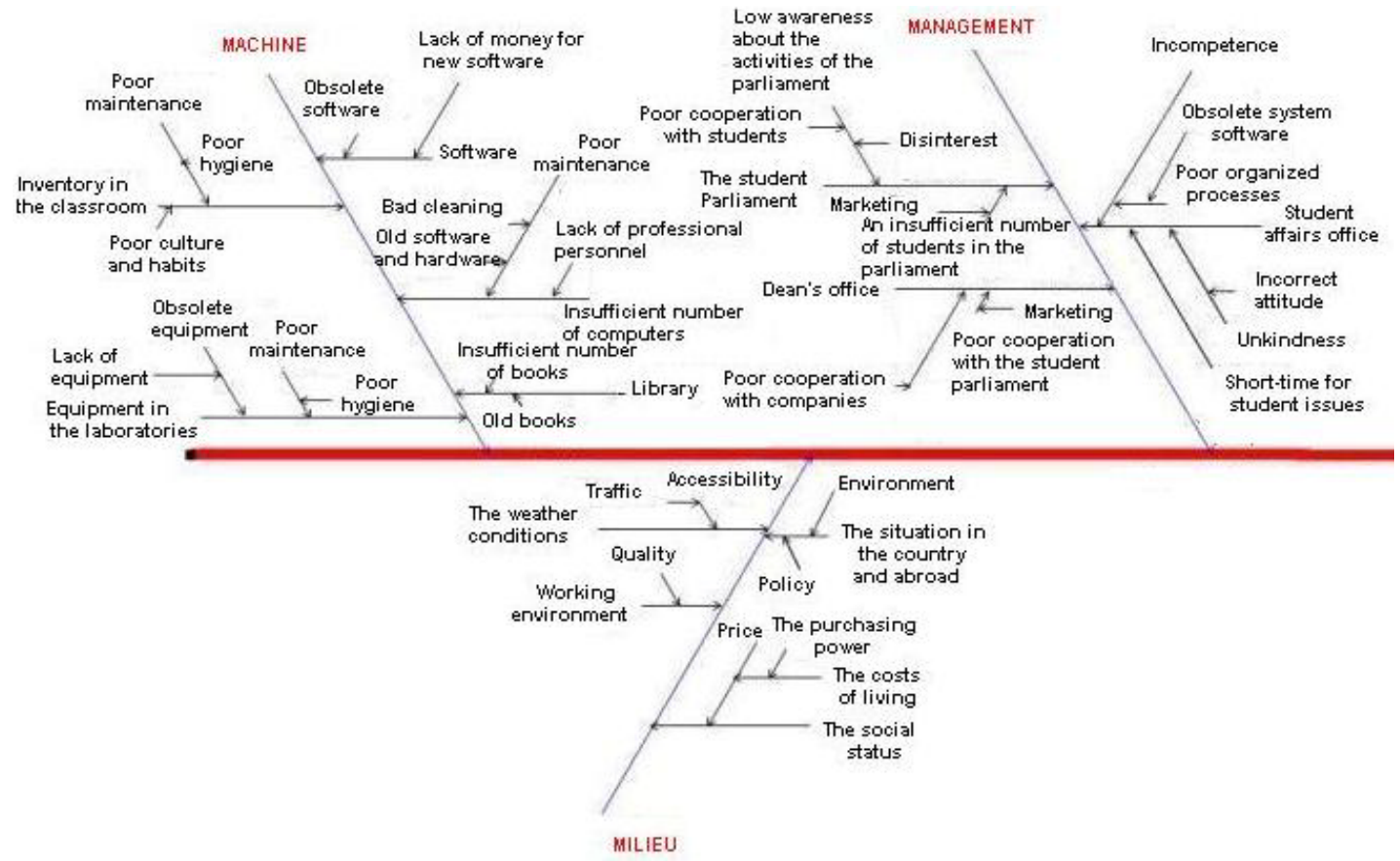

Figure 5. Categories Machines, Milieu and Management 
The main causes that as a consequence have Small number of passed exams can be found into two categories: Method and Man. One of the major problems of the small number of passed exams, detected in Ishikawa diagram, is the outdated teaching plan for most of the courses. What is learnt in courses does not follow the trend of required knowledge in the market, which results that students after graduation cannot apply their knowledge on 'real-life' problems.

Another problem is a manner of presentation, which has implied so far that a professor teaches in large groups of students. In this way professors are not able to answer students' questions or clarify their lectures in details.

The absence of students from classes and failure to fulfil the pre-exam requirements (seminar papers, homework and project tasks) directly affect the consequence observed in this case.

\section{SUGGESTED IMPROVEMENTS ACCORDING TO PREVIOUS RESULTS}

The vital minority of subjects that are critical for passing exams is determined using the Pareto analysis. After determining a vital minority and implementing SPC analysis, it is necessary to determine the root cause of the small number of passed exams. Ishikawa diagram shows the root causes which should be eliminated using available resources that would increase the number of passed exams.

Besides from the fact that professors have to change their teaching plans, they need to change the manner of presentation so that the courses become more interactive, where students will be more involved in the process of education. This means working with small groups of students where a professor will devote more time to students' questions and their needs, i.e. professor and students will make an effective team. In other words, a professor and students will become "partners" in the process of acquiring knowledge. These improvements will impact the elimination of another important problem which is the Lack of motivation of students and professors (Malik, 2010).

These are the reasons why the plan of improvement is determined. The improvement plan was made with the faculty management and professors of "critical subjects" and was implemented immediately after these analyses. In the period when the improvement plan was made the Bologna process was in the early stage of implementation not only at this Faculty but also in the entire University.

By implementing the Bologna process completely in all courses and changing the mode of taking an exam, these above mentioned problems will be solved. Examination procedure, which has so far consisted of written and oral part and where students could take exams only after the semester is finished, has been changed. Now, during the course, students do their homework, seminars and project tasks. By fulfilling their obligations, students can take exams during the semesters. In this way students are active throughout the entire semesters.

During the summer break, all classrooms at the faculty were cleaned, renovated and equipped with new furniture. All unnecessary items, materials, tools and equipment that are no longer in use were removed. Generally, now all rooms, machines, tools and equipment are more frequently cleaned, and as a result we have a clean and safe workplace, where each next 
occurrence of a failure, hazard or anomaly can be easily detected and eliminated in time.

\section{DISCUSSION OF RESULTS AFTER APPLYING LEAN SIX SIGMA METHODOLOGY}

As a result of implementation of the Lean Six Sigma method in the education process and implementation of improvement plan, there are more students who passed exams in 2012/2013 academic year. It can be noticed

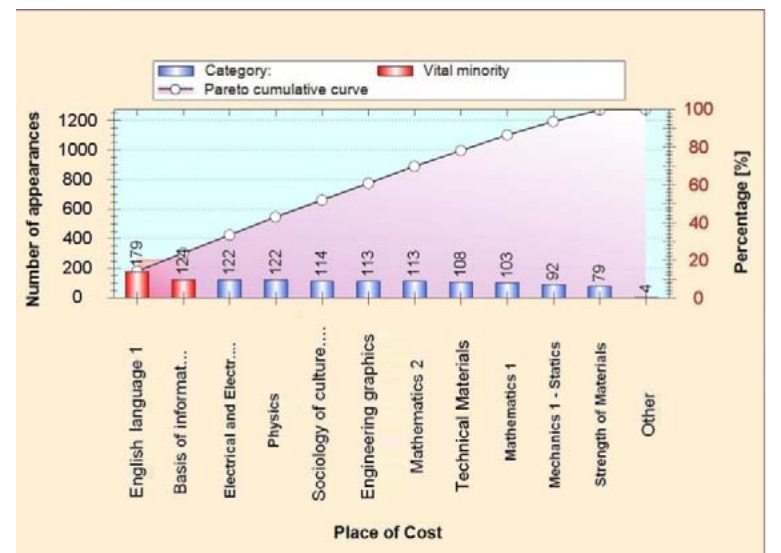

Figure 6. Pareto analysis of the number of passed exams in the first year of academic year 2009/2010

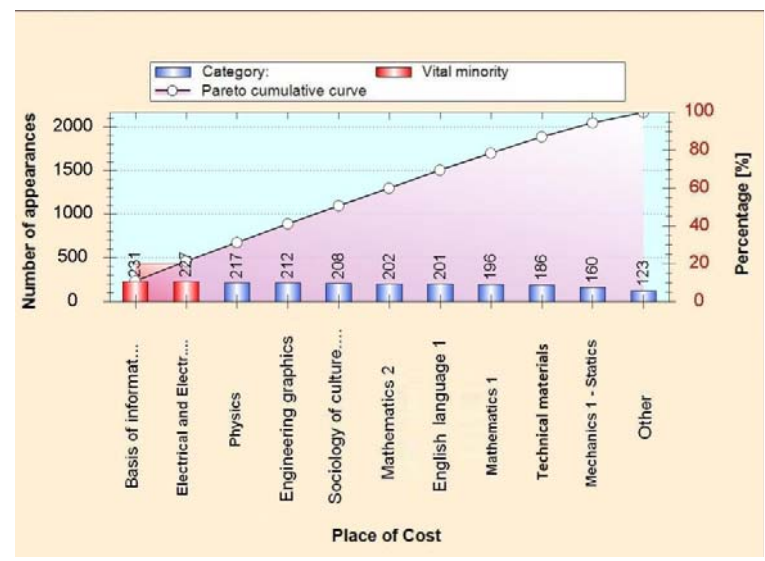

Figure7. Pareto analysis of the number of passed exams in the first year of academic year $2012 / 2013$ that not only the number of passed exams are increased but also there is a different redistribution of subjects that are passed successfully and that are not critical any more.

Comparative overview of Pareto analysis of the number of passed exams in the examination period for 2009/2010 and 2012/2013 academic year shows the results after application of Lean Six Sigma method (Figures 6 and 7).

\section{CONCLUSIONS}

Based on the locating and defining problems in the reform of higher education, especially at the Faculty of Mechanical Engineering University of Nis, measures and actions are proposed in this paper, which can eliminate any deficiency that exists in the process of reform and define the methods which may be used to improve the quality of teaching and students' success in the exam periods. It is expected that the implementation of the above mentioned improvements is just the beginning, and that the full implementation would increase even more the pass rate of students with maintaining the quality of the curriculum. In addition, it is necessary to emphasize the importance of continuous monitoring of all parameters that affect the students' success in the exam period and the quality of teaching process, and according to the results of analysis, identifying and implementing adequate procedures for the improvement of these parameters.

For future analysis it is planned to do detailed students' survey so the more adequate information can be involved in the analysis. In this way not only statistical data but also subjective opinion of students will 
be considered in future research.

The process of implementation of the Lean Six Sigma method requires some time, and it should be kept in mind that Lean Six Sigma is not a "final destination" but travelling that should be continuous. Another important factor is a change of organization culture, some changes of the attitudes of professors and students should be made and the way they communicate or cooperate.
The application of methods and changing of the culture are necessary conditions for employees' empowerment and commitment. The example presented in this paper confirms the usefulness of implementing the Lean Six Sigma methodology in a higher education process.

\section{УЛОГА МЕТОДА КВАЛИТЕТА У ПОБОЉШАЊУ ПРОЦЕСА ОБРАЗОВАНА: СТУДИЈА СЛУЧАЈА}

\section{Драган Павловић, Милена Тодоровић, Срђан Младеновић и Пеђа Милосављевић}

\section{Извод}

Овај рад приказује примену „Lean Six Sigma“ методе у процесу образовања. Након дефинисања недостатака које имају негативан утицај на квалитет високог образовања и начина како се ови недостаци могу отклонити, спроводи се Парето анализа како би се утврдила витална мањина предмета (испита) критичних за процес оцењивања на факултету, односно броја положених испита. Следећи корак је анализа Статистичке Контроле Процеса (СПЦ) у коју су укључени предмети који су Парето анализом класификовани као витална мањина. „Ishikawa” дијаграм показује однос између разматране последице (мали број положених испита) и свих фактора који утичу на ову последицу. На основу резултата примене „Lean Six Sigma“" методе у процесу образовања и имплементације свих предложених побољшања, дат је компаративни приказ Парето анализа за академску годину 2009/2010 и 2012/2013 на Машинском факултету Универзитета у Нишу.

Кључне речи: Lean, 6 сигма, парето, СКП, “Ishikawa” дијаграм, Образовање.

\section{References}

Banuelas, R., Antony, J., \& Brace, M. (2005). An application of Six Sigma to reduce waste. Quality and Reliability Engineering International, 21 (6), 553-570.

Basri, H. (2009). International benchmarking in higher education: A Case study for engineering education in Malaysia. The International Journal of Organization Innovation, 1 (3), 2-18.

Bhuiyan, N., \& Baghel, A. (2005). An overview of continuous improvement: From the past to the present. Management Decision, 43 (5), 761-771.

Enarsson, L. (1998). Evaluation of suppliers: How to consider the environment. International Journal of Physical Distribution \& Logistics Management, 28 (1), 5-17.

Ewell, P.T. (1993). Total quality and academic practise: The idea we've been waiting for? Change, 25 (3), 49-55. 
Glover, W., Liu, W-H., Farris, J., \& Van Aken, E. (2013). Characteristics of established kaizen event programs: An empirical study. International Journal of Operations \& Production Management, 33 (9), 1166-1201.

Goh, T.N. (2010). Six Sigma in industry: Some observations after twenty-five years. Quality and Reliability Engineering International, 27 (2), 211-227.

Grosfeld-Nir, A., Ronen, B., \& Kozlovski, N. (2007). The Pareto managerial principle: When does it apply?. International Journal of Production Research, 45 (10), 2317-2325.

Hampson, I. (1999). Lean production and the Toyota production system or, the case of the forgotten production concepts. Economic and Industrial Democracy, 20 (3), 369-391.

Helms, S., \& Key, C.H. (1994). Are students more than customers in the classroom?. Quality Progress, 27 (9), 97-99.

Hines, P., \& Rich, N. (1997). The seven value stream mapping tools. International Journal of Operations \& Production Management, 17 (1), 46-64.

Holweg, M. (2007). The genealogy of Lean production. Journal of Operations Management, 25 (2), 420-437.

Hu, G., Wang, L., Fetch, S., \& Bidanda, B. (2008). A multi-objective model for project portfolio selection to implement Lean and Six Sigma concept. International Journal of Production Research, 46 (23), 6611-6625.

Hwang, Y.D. (2006). The practices of integrating manufacturing execution system and Six Sigma methodology. International Journal of Advanced Manufacturing Technology, 30 (7-8), 761-768.

Ishikawa, K. (1982). Guide to quality control. 2nd Edition. Tokyo, Japan: Asian Productivity Organization.

Karapetrović, S., \& Willborn, W. (1997). Creating zero-defect students. TQM
Magazine, 9 (4), 287-291.

Linderman, K., Schroeden, R., Zaheer, S., \& Choo, A. (2003). Six Sigma: A goaltheoretic perspective. Journal of Operations Management, 21 (2), 193-203.

Malik, N. (2010). A study on motivational factors of the faculty members at University of Balochistan. Serbian Journal of Management, 5 (1), 143-149.

Olivia, M.S., \& Aspinwall, E.M. (1997). TQM in higher education - a review. International Journal of Quality \& Reliability Management, 14 (5), 527-543.

Paramasivam, S., \& Muthusamy, K. (2012). Study of critical success factors in engineering education curriculum development using Six-Sigma methodology. Procedia - Social and Behavioral Sciences, 56, 652-661.

Peitz, M., \& Shin, D. (2013). Innovation and waste in supply chain management. Journal of Economic Behavior \& Organization, 86, 191-199.

Quinn, A., Lemay, G., Larsen, P., \& Johnson, D.M. (2009). Service quality in higher education. Total quality management and business excellence, 20 (2), 139-152.

Raisinghani, M.S., Ette, H., Pierce, R., Cannon, G., \& Daripaly, P. (2005). Six Sigma: Concepts, tools, and applications. Industrial Management \& Data Systems, 105 (4), $491-505$.

Scott, P., \& Leach, J. (2003). Individual and sociocultural views of learning in science education. Science \& Education, 12 (1), 91-113.

Shan, R., Chandrasekaran, A., \& Linderman, K. (2008). In pursuit of implementation patterns: The context of Lean and Six Sigma. International Journal of Production Research, 46 (23), 6679-6699.

Shah, R., \& Ward, P.T. (2007). Defining and developing measures of Lean 
production. Journal of Operations Management, 25 (4), 785-805.

Stoiljković, V., Milosavljević, P., \& Ranđelović, S. (2010). Six Sigma concept within banking system. African Journal of Business Management, 4 (8), 1480-1493.

Tribus, M. (2005). Some remarks on the improvement of engineering education. Journal of Science Education and Technology, 14 (1), 1-28.

Womack, J.P., \& Jones, D.T. (2003). Lean thinking, Free Press. New York, NY, USA: Simon \& Schuster Inc.

Womack, J.P., Jones, D.T., \& Roos, D. (1990). The machine that changed the world: The story of Lean production. New York, NY, USA: Rawson and Associates. 